\title{
THREE 'FORGOTTEN' CITYSCAPES OF MECHELEN IN THE LATE SIXTEENTH CENTURY: THE SPANISH AND ENGLISH FURIES IN MECHELEN $(1572,1580)$ THROUGH THE EYES OF CONTEMPORARIES ${ }^{1}$
}

\author{
Bram CAers
}

\begin{abstract}
The Royal Library of Belgium holds three peculiar cityscapes of the city of Mechelen that have not been studied in any detail before. They show the city in two of its most distressful moments: the Spanish (1572) and English (1580) furies, both gruesome episodes in the Dutch Revolt. The present article is a first attempt to place the cityscapes in a wider context. It provides an overview of the history of the city of Mechelen in the late sixteenth century and then moves on to a closer study of the cityscapes in question. By looking at contemporary sources of a similar nature (cartography, printed depictions of the Revolt) and by sketching the outlines of the contexts in which these sources were produced and circulated, it hopes to provide new insight into the cityscapes under scrutiny, as well as to the function of similar sources in the post-Revolt Low Countries.
\end{abstract}

When in the second half of the sixteenth century, a wave of religious and political unrest swept through the Low Countries, the city of Mechelen was not spared. ${ }^{2}$ Having been left relatively untarnished by the Iconoclasm (1566), it paid a far higher price in the following decades. It was pillaged and plundered by both the Spanish army under Alva ('Spanish Fury', 1572) and the rebel mercenary forces ('English Fury', 1580). Furthermore, its own moderately anti-royalist magistrate had decided in 1578 to burn down any buildings outside the walls for defensive reasons, fearing the loyalist forces would use the outskirts as cover in case of a prolonged siege. ${ }^{3}$ Mechelen in the 1580 s must have looked a faint shadow of

(1) I would like to thank Colin Dupont (Royal Library of Belgium) for his useful help in reacquainting myself with the cityscapes under scrutiny and for pointing me to numerous useful references.

(2) For a general overview of Mechelen in the sixteenth century, see R. Van Uytven, De geschiedenis van Mechelen: van heerlijkheid tot stadsgewest (Tielt: Lannoo, 1991). Part of the chapters on the religious unrest were written by Guido Marnef, who dealt specifically with this topic in Het calvinistisch bewind te Mechelen (Kortrijk/Heule: UGA, 1989). (Standen en landen; LXXXVII).

(3) All three traumatic occurrences in the history of Mechelen have received unequal attention in secondary literature. For a general overview, see Marnef's chapter in Van Uytven, De geschiedenis van Mechelen, 124-128. Comp. on the Spanish Fury of 1572: Marnef, Het calvinistisch bewind, 80-81; on the destruction of the outskirts: Idem, 91-92; and on the English Fury, Idem, 143-146. Marnef based his account on contemporary and later chroniclers such as G.D. de Azevedo Coutinho y Bernal and Emmanuel van Meteren. J.J. De Munck, Gedenkschriften van den H. Rumoldus van Mechelen (Leuven: Van der Elst, 1777) provides detailed accounts of the destruction of religious heritage. The destruction of specific religious buildings can also be traced in 
its counterpart in the 1560s, when Lodovico Guicciardini had praised its beauty in his acclaimed description of the Low Countries. ${ }^{4}$ Indeed, contemporary voices strongly deplored the repeated destruction of the city in this relatively short span of time. ${ }^{5}$

Even if Mechelen was not a strategic asset in a strictly military sense, it was an important symbol of power and its fate for this reason resounded throughout the Low Countries and at the courts of Europe. As the seat of the central court of appeal for the entire Habsburg Low Countries (1473-1477, and later from 1503 onwards), it was the embodiment of the concentration of judicial power in the hands of central authority. Certainly after 1546, when a devastating explosion in Mechelen damaged much of the splendorous government buildings and stately residences of noble dignitaries, Mechelen had lost its role as a princely court, but it would remain the judicial capital of the (southern) Low Countries up until the French Revolution, albeit with short intervals. ${ }^{6}$ Alongside its central function in terms of politics, Mechelen was also the seat of an archbishop, who wielded metropolitan authority over the entire Low Countries ever since the religious reforms of $1559 .^{7}$

Being the culmination of both centralised justice and the catholic religion in the Low Countries, Mechelen therefore symbolized the powers of Church and King, precisely those powers against which resistance was rising throughout the lands. Moreover, especially the high court stood for the efforts of generations of Valois and Habsburg dukes and archdukes to centralise power in their ever-growing state complex, much to detriment of the powerful cities, which were traditionally strong-headed when it came to their political independence. ${ }^{8}$ While in cities such as Antwerp and Ghent, the uprising was broadly supported among the populace and resulted in successful establishments of Calvinist regimes, Mechelen seems to have remained in doubt between either side of the political divide throughout the sixteenth

H. Installé (ed.), Historische stedenatlas van België: Mechelen II (Handelingen van de Koninklijke Kring voor Oudheidkunde, Letteren en Kunst van Mechelen, 1997).

(4) The original Descritione di tutti I paesi bassi was printed in Antwerp in 1567, but for convenience sake, I refer here to the Dutch translation by Cornelis Kiliaan: L. Guicciardini, Beschryvinghe van alle de NederLanden anderssins ghenoemt Neder-Duytslandt, door M. Lowijs Guicciardijn... Amsterdam: Willem Jansz, 1612. The decription of Mechelen here is on pages 131-135 [Facsimile edition, Amsterdam: Facsimile Uitgaven Nederland, 1968].

(5) Marnef, Het calvinistisch bewind, 146 quotes Emmanuel van Meteren.

(6) L.T. Maes, Het Parlement en de Grote Raad van Mechelen (Antwerpen/Rotterdam: De Vries-Brouwers, 2009). On the effect of the disaster of 1546 on Mechelen's political role, see, 117-118.

(7) General information is in Van Uytven, De geschiedenis van Mechelen, 83-116 (contributions by W. Mertens, R. Van Uytven, E. van Autenboer, M Eeman and H. Vlieghe). On the central court (in judicial terms), see more specifically L.T. Maes, Het parlement en de Grote Raad van Mechelen.

(8) A recent overview of this 'prelude' to the sixteenth-century is R. Stein, De hertog en zijn staten: de eenwording van de Bourgondische Nederlanden, c. 1380-1480 (Hilversum: Verloren, 2014). English translation: Magnanimous dukes and rising states: the unification of the Burgundian Netherlands, 1380-1480 (Oxford: Oxford University Press, 2017). The irony is that in the newly forming rebellious state under the Estates-General, the question of particularism (both on the level of the regions as on that of the cities) turned out to be an issue as well, with William of Orange pleading for more central authority, see Marnef, Het calvinistisch bewind, 142. 
century. ${ }^{9}$ Even if in Mechelen too, a Calvinist regime was installed that would remain in place for five years (1580-1585), it enjoyed far less broad public acclaim than its counterparts elsewhere. It was essentially established in blood, not through a willing overhaul of the urban administration. ${ }^{10}$ The reconciliation of the city under Alexander Farnese on the initiative of loyal elements in the urban council was perceived as a return to just Habsburg rule, much more than was the case in Antwerp or Ghent for example. Partly, this had to do with the fact that the city had been brought under Calvinist dominion by military force. ${ }^{11}$ But another part of the explanation for Mechelen's reluctant embrace of rebel rule - and by extension, of Calvinism - may lie in the city's long-standing tradition of loyalty towards central authority. In this respect, it certainly stands out when compared to more tenacious cities such as Ghent, known for centuries for their difficult relationship with subsequent princes and their stubborn insistence on the primality of urban power. ${ }^{12}$ Another reason for Mechelen's relatively easy return to the bosom of royal Habsburg authority in 1585 could well be its complete and utter tiredness of war. After the systematic pillaging ordered by the duke of Alva in 1572 (the so-called Spanish Fury), the complete destruction of all buildings outside the walls in 1578 , followed by a new sack, now by Calvinist mercenary forces, which lasted for a month in 1580, Mecheleners desperately craved the restoration of peace. In the war-torn Low Countries, bereft of any support from neighbouring Calvinist regimes, a return to Habsburg rule therefore was a tempting prospect for the city, certainly when this would mean that its former functions as a seat of the archbishopric and of the high court - the latter was formally moved to Mons and Namur during the Calvinist regime - would be restored. ${ }^{13}$ It was a plain choice between being forever stripped of its central role, degraded to a peripheral city in the slowly forming body of what would

(9) Marnef, Het calvinistisch bewind, passim. The rebellious attitude of the other cities (and the relative loyalty of Mechelen, for that matter) at least in part coincided with their tenacious attitudes in the past, see for example J. Dumolyn \& J. Haemers, 'Patterns of urban rebellion in medieval Flanders,' Journal of medieval history 31 (2005), 369-393.

(10) Marnef, Het calvinistisch bewind, 141-146, shows how the regime essentially was a coup, orchestrated in Antwerp, on a moderately royalist and catholic urban administration established in 1579. The new magistrate benches were filled with Calvinist dignitaries from outside the city (see p. 151), which certainly did not help gain support.

(11) Marnef, Het calvinistisch bewind, 310-311.

(12) See for example: M. Boone, 'The Dutch Revolt and the medieval tradition of urban dissent,' Journal of Early Modern History II.4-5 (2007), 351-375. Loyalty was a main theme in the historiography of Mechelen en seems to have been the main programme of its politics towards central authority. See, from the perspective of urban historiography, B. Caers. Vertekend verleden: geschiedenis herschrijven in vroegmodern Mechelen, $1500-$ 1650 (Hilversum: Verloren [in press]).

(13) Mechelen was an enclave within the duchy of Brabant and its trade was blocked off by its Brabantine neighbours both on water and on land. In the middle ages, this had caused several conflicts (see Caers, Vertekend verleden, 191-276), but in the sixteenth century too, Mechelen's neighbours did not hesitate to boycott its trade to pressure the city into obedience (see Marnef, Het calvinistisch bewind, 131. On Mechelen's efforts to regain its former position as seat of the Great Council, see Marnef, Het calvinistisch bewind, 321-322. 
become a predominantly Calvinist Republic, or indeed to return to its former glory under Habsburg domination.

As was the case throughout the Southern Low Countries, political elites were shaken to their cores by the events of the Rebellion. Many who had opposed Habsburg rule, or certainly those who had openly converted to Calvinism, moved to cities in the North when the southern Low Countries were gradually retaken by Alexander Farnese. In the void of power left by these emigrants, opportunities arose for new elites. ${ }^{14}$ In Mechelen, the newly restored city council of 1585 was dominated by loyal Catholics, part of whom had never occupied positions of power in Mechelen before. ${ }^{15}$ Here and in other cities, the Habsburg authority stimulated the influx of new, loyal figures in urban government - loyal, that is, to both king and church. ${ }^{16}$ I have shown elsewhere that in the years and decades following 1585, the catholic elite of the city of Mechelen spared no effort to publicly affirm its loyalty to central authority and its triumphant return to the bosom of the catholic faith and the protection of the crown. What I have called a conscious 'cultuurpolitiek' - cultural policy - manifested itself through iconography, historiography, literature and religious art, well into the early decades of the seventeenth century. ${ }^{17}$ The city in this way actively inscribed itself in a Counter Reformation ideal that swept the southern Low Countries after the reconciliation. The message clearly was that after decades of troubles, Mechelen had returned to its rightful place in the constellation of the Habsburg empire, namely as a loyal city, seat of power in both religious and political terms.

At the same time, the catholic opinion in Mechelen was not the only one. Families who had dominated the city's bodies of power for generations, were torn apart between either sides of the political divide. ${ }^{18}$ Scions of some of the city's most illustrious families would go on to play important parts in the north. For example: three members of the Van der Aa family figure on the 'Eedverbond der Edelen' the formal complaint of the Low Countries' nobles to regent Margaret of Parma in 1566, among other families that either hailed from Mechelen or participated in its power structures. ${ }^{19}$ A notable example of a Mechelen Calvinist is that of Willem de Gortter, scion of an important family that had been wielding

(14) See in general: J. S. Pollmann, Catholic Identity and the Revolt of the Netherlands, 1520-1635. (Oxford: Oxford University Press, 2011). For Mechelen, compare Marnef, Het calvinistisch bewind, 309-322.

(15) Marnef, Het Calvinistisch bewind, 312-313. Compare B. Caers, 'In fide constans? Politiek van herinnering in het Mechelse stadsbestuur,' De zeventiende eeuw 29 (2013) 2, 228-246, here 242-244.

(16) Pollmann, Catholic identity, 138-141.

(17) Caers, 'In fide constans?', passim.

(18) One look at the list of political elites in Marnef, Het calvinistisch bewind, would suffice to confirm this assumption. Comp. Caers, Vertekend verleden, 149-150 and the case of the Van der Veken family from Mechelen, in Marnef, Het calvinistisch bewind, 375-376; and H. Rau, 'De Mechelaar Jan Van der Veken, "een koopman van international allure" te Rotterdam,' in Handelingen van de Koninklijke Kring voor Oudheidkunde, Letteren en Kunst van Mechelen 88 (1984) 2, 122-127.

(19) G. Bonnevie-Noël, 'Liste critique des signataires du compromis des nobles,' Vereniging voor de geschiedenis van het Belgisch protestantisme, Vijfde reeks, III (1968), 80-110. 
political power in the city for centuries, but that had somewhat dwindled in importance in the course of the sixteenth century. ${ }^{20}$ Around 1600, he compiled a manuscript of songs that is a splendid statement of his refutation of Habsburg rule. Around and in between triumphant drawings of key figures in the uprising, he has noted down protestant songs and political poems, including what is today cherished as the earliest handwritten recording of the Wilhelmus, the present-day anthem of the Netherlands. ${ }^{21}$ De Gortter, as well as other examples, shows that the divide between Catholics and Protestants in Mechelen as elsewhere, was a nuanced one. It is easy to state that Mechelen was univocally catholic after 1585 , but this would be imprecise. While the city council actively propagated a loyal position towards both King and Church, individuals could indeed cherish different opinions.

It is against this backdrop that we should see three cityscapes of the city of Mechelen that are today in the custody of the Royal Library of Belgium, under reference II $1388 .{ }^{22}$ Apart from being mentioned in the catalogue that J. Van den Gheyn drew up of the library's manuscript holdings, there has been no scholarly attention for these cityscapes to my knowledge. ${ }^{23}$ When looking for iconographical sources on the subsequent sacks of Mechelen, scholars have generally turned to contemporary or later engravings, such as Frans Hogenberg's widely dispersed series depicting the various key moments in the uprising against Habsburg rule in the context of a Latin history of the Rebellion written by the Austrian nobleman Michael Aitsinger. ${ }^{24}$ Hogenberg's engravings soon circulated in loose form or in separate series and formed the basis for later copies and followers. ${ }^{25}$ Possibly because of the fame of this iconography, and indeed its wide availability in print, the manuscript and watercolour depictions of the same events succeeded in escaping attention for such a long time. In this article, I wish to introduce these three cityscapes to fellow scholars as an alternative depiction of the horrid events in Mechelen in the 1570s and 1580s, as well as an intriguing addition to ongoing debates about cartography and

(20) Research database by Pieter Verhoeven (University of Antwerp), based on A. Van den Eynde, Tableau chronologique des écoutètes, des bourgemestres et des échevins, depuis 1236 jusqu’à nos jours, ainsi que les sceaux des premiers seigneurs de la ville de Malines. (Mechelen: Van Velsen, 1859).

(21) Royal Library of Belgium, Manuscript 15.662.

(22) They were catalogued as part of the Manuscripts department by Van den Gheyn, Catalogue des manuscrits de la Bibliothèque Royale de Belgique. (Bruxelles: Lambertin, 1901-1948), t. 8, 104-105, but have been transferred to the collection of maps. The sheets have been digitized and are now accessible through the Royal Library's online catalogue.

(23) The cityscapes were first brought to attention in B. Caers, Vertekend verleden, 103 but have not been discussed in any detail before.

(24) M. Aitsinger (also: Aitzing, Aitzinger, Eytzinger, Eytzing, etc.), De leone belgico... cum figuris Francisci Hogenbergii... Cologne: [s.n.], 1588. A first edition was printed in 1583. I used the later edition of 1588 present in the Royal Library of Belgium: Precious Books, II 17.129 B (LP).

(25) H. Installé, 'Eigentijdse (tot 1800) oude gedrukte plattegronden en panoramische gezichten van Mechelen,' in H. Installé, Hans Rombauts \& Godfried Croenen, Historische stedenatlas van België: Mechelen. (Brussel: Gemeentekrediet, 1997), 29-54, here 36. 
chorography in Mechelen in the course of the sixteenth and seventeenth centuries. ${ }^{26}$ Even though not all three of them include descriptions, I will show that they depict distinct stages of the city of Mechelen in the second half of the sixteenth century, namely that of the city in its untarnished state, followed by the Spanish Fury of 1572 and the English Fury of 1580. As far as I can see, they present entirely new iconographical depictions of the city of Mechelen, which makes them an interesting addition to the available material in terms of iconography and cartography.

The three cityscapes are kept in a rather worn-down cardboard folder, most likely since their acquisition by the Royal Library in 1891. ${ }^{27}$ The documents themselves then, are three sheets of parchment that seem to have been originally all folded in half, and possibly glued together as three small one-sheet quires into a little booklet (there are no sewing holes, so they have never been bound). Today, however, the three sheets are kept loose from each other and unfolded. From the inconsistency of the wearing patterns and various staining, it can be assumed that they had been kept loose from each other for some time when the Royal Library acquired them. The same is suggested by the places where they were stamped and labelled upon acquisition. At this point, they were given numbers from one to three (written down in pencil) and provisional French titles (in ink). For reasons of convenience, I will stick to these, even if I am not convinced that the titles are entirely accurate or the chronology between the drawings is the same as the order given upon acquisition.

Each of the three sheets shows the city of Mechelen in a pen and ink watercolour drawing, from various bird's-eye perspectives. For this reason, I consistently speak of 'cityscapes' as opposed to plain maps. Because they are presently kept loose from each other, and their original order is unclear, I will treat them as three different quires, each with two folios 1 and 2 , with $1 \mathrm{v}-2 \mathrm{r}$ being the unfolded cityscape.

\section{REPRISE DE MALINES PAR LE DUC D’ALBE, LE 2 OCTOBRE 1572}

Parchment, approximately $335 \mathrm{~mm}$ by $240 \mathrm{~mm}$. Folio $1 \mathrm{r}$ shows contemporary writing in Latin, in Roman type, and High German, in 'Fraktur' type. Because it is the only sheet with contemporary writing, and because of the way of folding, it may well have served as a type of title page for the three-quire booklet that the cityscapes could have formed in their day. Folio $2 \mathrm{v}$ shows the nineteenth-century marks of the acquisition by the Royal Library (label, stamp, pencil and ink notes).

(26) See Caers, Vertekend verleden, 96, n. 241.

(27) The cityscapes were acquired on 4 August 1891 for the sum of 15 francs from a certain 'Mme NiteletDe Roy', living in Brussels at the time. Brussels, Royal Library, Manuscript Acquisition Register. 


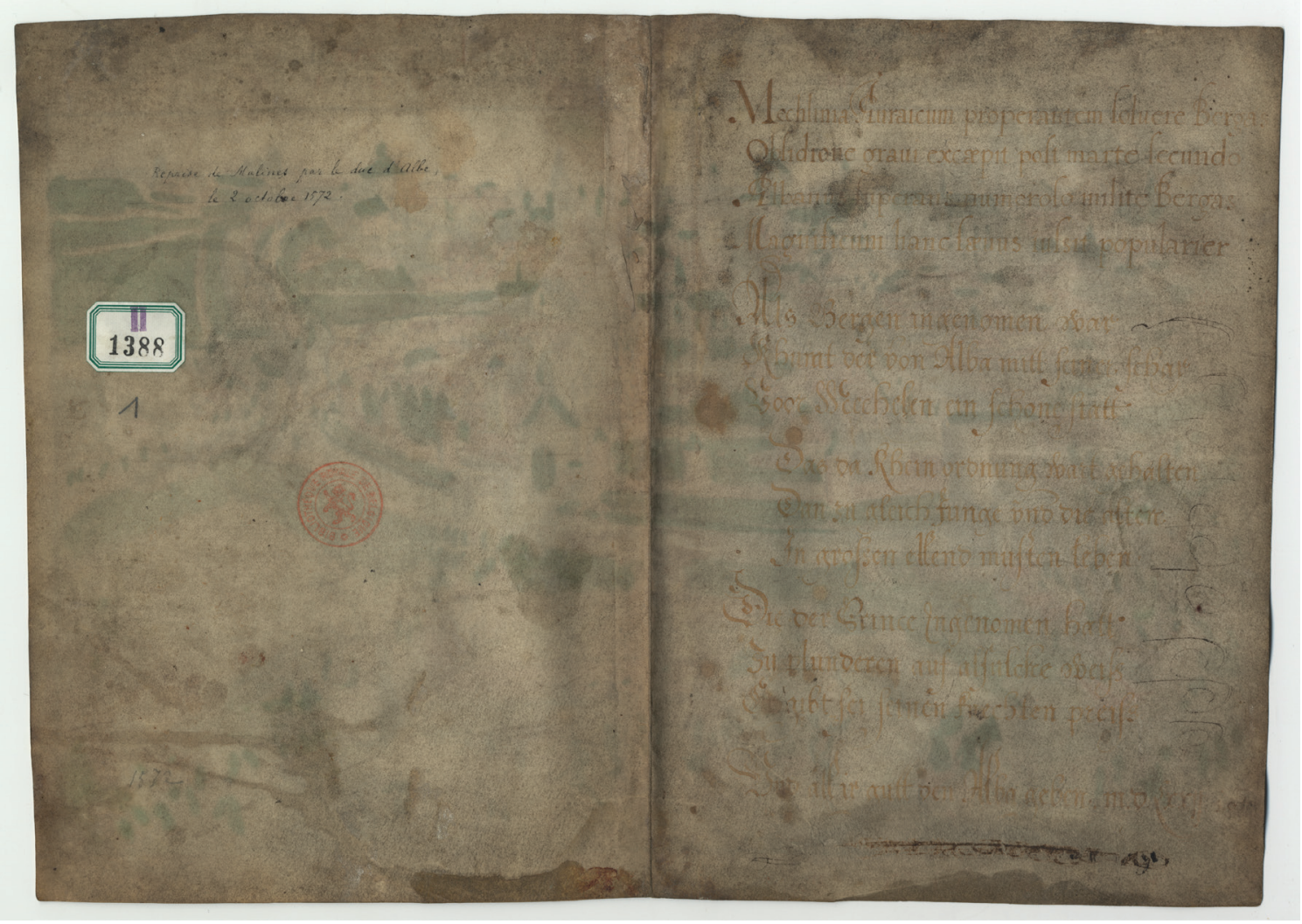

[Fig. 1: fol. 1r, 2v]

Anonymous artist, [Reprise de Malines par le duc d'Albe, le 2 octobre 1572], Royal Library of Belgium, II 1388, fols 1r-2v]

The Latin lines on $\mathrm{f} .1 \mathrm{r}$ read as follows:

Mechlinia Auraicum properantem solvere Bergas obsidione graui excaepit post Marte secundo Albanus superans numeroso milite BERGAS Magnificam hanc saevus iussit popularier ${ }^{28}$

In this form, they figure as an inscription on an engraving depicting the Spanish Fury in Mechelen in 1572 that is a part of William Baudartius' Latin history of the Rebellion, printed in Amsterdam in 1622. ${ }^{29}$ The engraving itself, however, is said to be based on work by Hogenberg and is dated between 1613 and $1615 .{ }^{30}$

(28) Translation, kindly provided by Jeanine De Landtsheer: 'Mechelen had received Orange, who hurried to relieve Mons of a grave siege during his second campaign. When Alva then conquered Mons with a large force, in his unsparing cruelty he ordered it destroyed.'

(29) Guilhelmus Baudartius, Viva delineatio, ac descriptio omnium proeliorum, obsidionum, aliarumque rerum... Amsterdam: Michael Colinius [Michiel Colijn], 1622, 99-101, the engraving is on page 101.

(30) F. Muller, De Nederlandsche geschiedenis in platen: beredeneerde beschrijving van Nederlandsche historieplaten, zinneprenten en historische kaarten. (Amsterdam: Muller, 1863-1882), (4 parts). T. 1, 83, nr. 595a. 
The text in a neatly written German Fraktur type reads as follows:
Als Bergen ingenomen war
Khumt der von Alba mitt seiner schar
Voor Mechelen ein schone statt
Das da khein ordnung wart gehalten
Dan zu gleich Junge und die alten
In grossen ellend musten leben
Die der Prince ingenomen hatt
$\mathrm{Zu}$ plunderen auf alsulcke Weiss
Er gibt sei seinen knechten preis
Und all ir gutt den Alba geben MDLXXII

These German verse lines also figure on more or less contemporary engravings, this time by Frans Hogenberg. ${ }^{31}$ There are some minor differences however. The spelling in this version at some points is closer to contemporary Dutch than the German of the engraving (e.g. ingenomen vs. original ingenommen, or Voor Mechelen instead of original vor Mechlen). This does not have any influence on the interpretation. More important is the mixing up of several parts of the poem. In fact, in the engraving, the third stanza quite rightly is the second, which makes more sense. Apparently, whoever noted down these verses on the parchment of the watercolour cityscape, made a mistake in copying them from an original engraving.

Folios $1 \mathrm{v}-2 \mathrm{r}$ show the city of Mechelen in an ink and watercolour drawing, set in a thick black frame, in the manner of sixteenth-century woodcuts, measuring approximately 325 by $200 \mathrm{~mm}$. The rather narrow margins are filled with three chronogrammatic riddles, each leading to the year 1572, in which the horrid depicted events took place (for the convenience of counting, I capitalized the letters to be counted for the chronogram, which are in red ink in the manuscript):

hIspanIs beLgIs MeChLInIa beLLo seCUndo

heU doLor oCtobrIs aspera praeda fUIt

MeCheLen saL ten eeUUIghen daghen

den tUUeeden daCh oCtobrIs beCLaghen

sICCIne VICta IaCes MeChLInIa VIrgo sUperba

These chronogrammatic riddles are not unique. They can be encountered in other sources, both in manuscript and in print, both narrative and iconographical. The first riddle figures on an engraving by Frans Hogenberg that forms part of Michael Aitsingers history of the Rebellion, first printed in 1583 in Cologne. ${ }^{32}$ The second one is referred to by Baudartius

(31) F. Muller, De Nederlandsche geschiedenis in platen, t. 1, 48, nr. 413/128.

(32) Also in Aitsinger, De leone belgico, 131. The subsequent engraving, however, is not consistent with the watercolour depiction: it shows a scene of plunder on the Great Market Place of Mechelen. 
an can be found in several manuscript chronicles predating Baudartius by a considerable margin. ${ }^{33}$

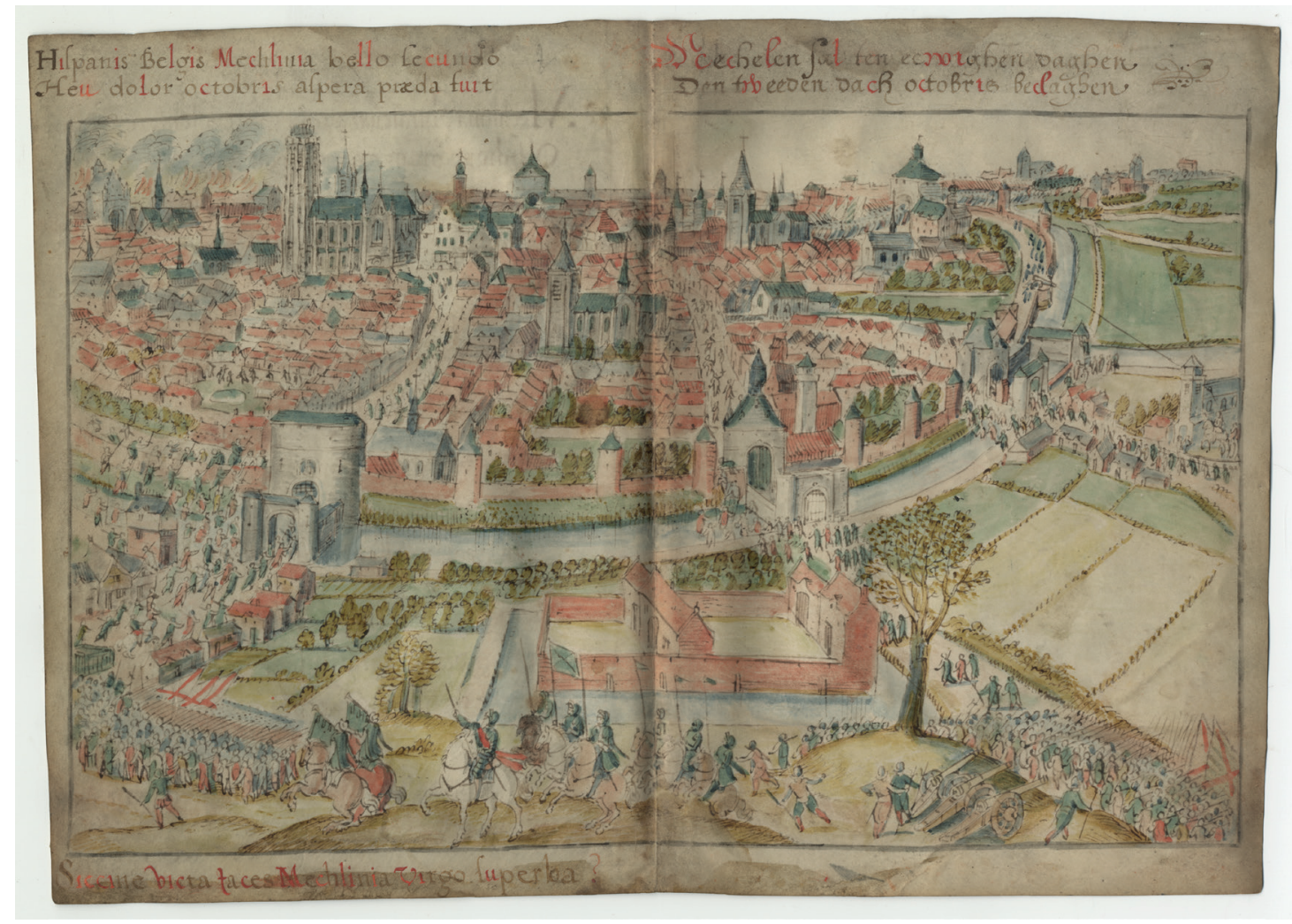

[Fig. 2: $1 \mathrm{v}-2 \mathrm{r}$ ]

Anonymous artist, [Reprise de Malines par le duc d'Albe, le 2 octobre 1572], Royal Library of Belgium, II 1388, fols 1v-2r]

The cityscape, then, shows the city of Mechelen from the south side, between the Brusselpoort (Brussels gate; still extant today, opening onto Hoogstraat) and the Overste Poort ('greater' gate; demolished in the 1960s, opening onto Bruul)..$^{34}$ Between these, still outside the walls, is the duke of Alva on a prancing horse, clearly depicted as the instigator of the deliberate plunder. Around him advance the troops under their red Burgundian cross banners, entering the city of Mechelen both through its gates and over its moats and walls. The northwest side of the city, depicted in the upper left corner, is burning, while the northeast side shows the flight of the protestant troops through Nekkerspoel gate, recognisable by

(33) Baudartius, Viva delineato, p. 100. An example of a chronicle is Mechelen, City Archives, EE VI 1, in which the chronogram not only prominently figures on the title page, but has also been included on a loose slip of parchment. See B. Caers, Vertekend verleden, 81-131, for a detailed study of this manuscript, which was written in different stages (and by different chroniclers) between 1542 and 1583 .

(34) About the Mechelen gates and their fate after the Ancien Regime, see M. Kocken, 'De stadsomwallingen en -poorten,' in H. Installé, Historische stedenatlas van België: Mechelen II, 190-201. 
their blue-and-white banners. Interestingly, these resemble some of the banners actually used by rebellious captains in the city of Mechelen, albeit not always in the right period. ${ }^{35}$ In the bottom right hand corner of the image (2r), the drawing shows how the fleeing rebels, while the royalist soldiers are swarming into the city elsewhere, fire a last desperate shot at a church outside the walls (into the church of Muizen). An uninteresting detail in appearance, this shot is actually known to have been taken indeed. The desperate last attempt of the rebels has also been recorded in chronicles, which may point to a shared source or to a wider knowledge of this anecdote among contemporaries. ${ }^{36}$

\section{SURPRISE DE MALINES PAR LES TROUPES DES ÉTATS, LE 9 AVRIL 1580}

Parchment, approximately $335 \mathrm{~mm}$ by $240 \mathrm{~mm}$. Folio $1 \mathrm{r}$ is blank, but shows traces of an erased ownership mark that, judging from the little that remains, may be dated to the seventeenth or eighteenth centuries. There are also traces of a vanished wax seal or stamp. $1 \mathrm{v}-2 \mathrm{r}$ shows an ink and watercolour drawing of the city of Mechelen, seen from the south (albeit slightly more to the west than before). $2 \mathrm{v}$ shows the ownership marks of the Royal Library. The staining and the central fold seem to indicate that the cityscape has been kept unfolded for a long time.

The ink and watercolour depiction of the city of Mechelen, measuring approximately 190 by $310 \mathrm{~mm}$, is drawn from a slightly higher perspective than that of 1572 . It shows more of the northern countryside behind the city than was possible in the drawing discussed above. From the onset it is clear that the basic iconographic programme is so similar that the present cityscape can be said to have been based on the previous. Based on the comparison of the individual soldiers, I would say that both were made by the same artist. This cityscape too is surrounded by a black frame, but lacks the chronogrammatic riddles in the margins and therefore makes a less lively impression. This is helped by the fact that there is far less 'movement' in the depiction. There are fewer soldiers, there is no fire and the outskirts of the city are depicted as less densely built than in the depiction of the Spanish Fury of 1572. Of course, any depiction of the English Fury does not need the duke of Alva on a prancing horse in the foreground. Still, the soldiers are very similar to the ones in 1572, even in their ways of entering the city. Again, a banner clearly links them to the rebels. In this case, the historical connection is even very precise: the white banner with a blue diagonal was indeed the one wielded by two rebel companies of militia who were involved in the plunder and sack of Mechelen in $1580 .^{37}$

(35) Compare the blue-and-white banners in the manuscript by Willem de Gortter: Brussels, Royal Library, Ms. 15.662, fols 3r, 5r, 6r. See also Marnef in Van Uytven, De geschiedenis van Mechelen, 131.

(36) See for example G.D. de Azevedo Coutinho y Bernal, Vervolg der cronycke van Mechelen t'Sedert de Maendt Junius 1572 tot 4 September 1576 (Leuven: Van der Haert [1773]).

(37) The banner could be that of Samuel van Alveringen (Brussels, Royal Library, ms. 15.662, fol. 6r), who commanded a company of militia in the taking of Mechelen in 1580 and until his death in 1581, see Marnef, 


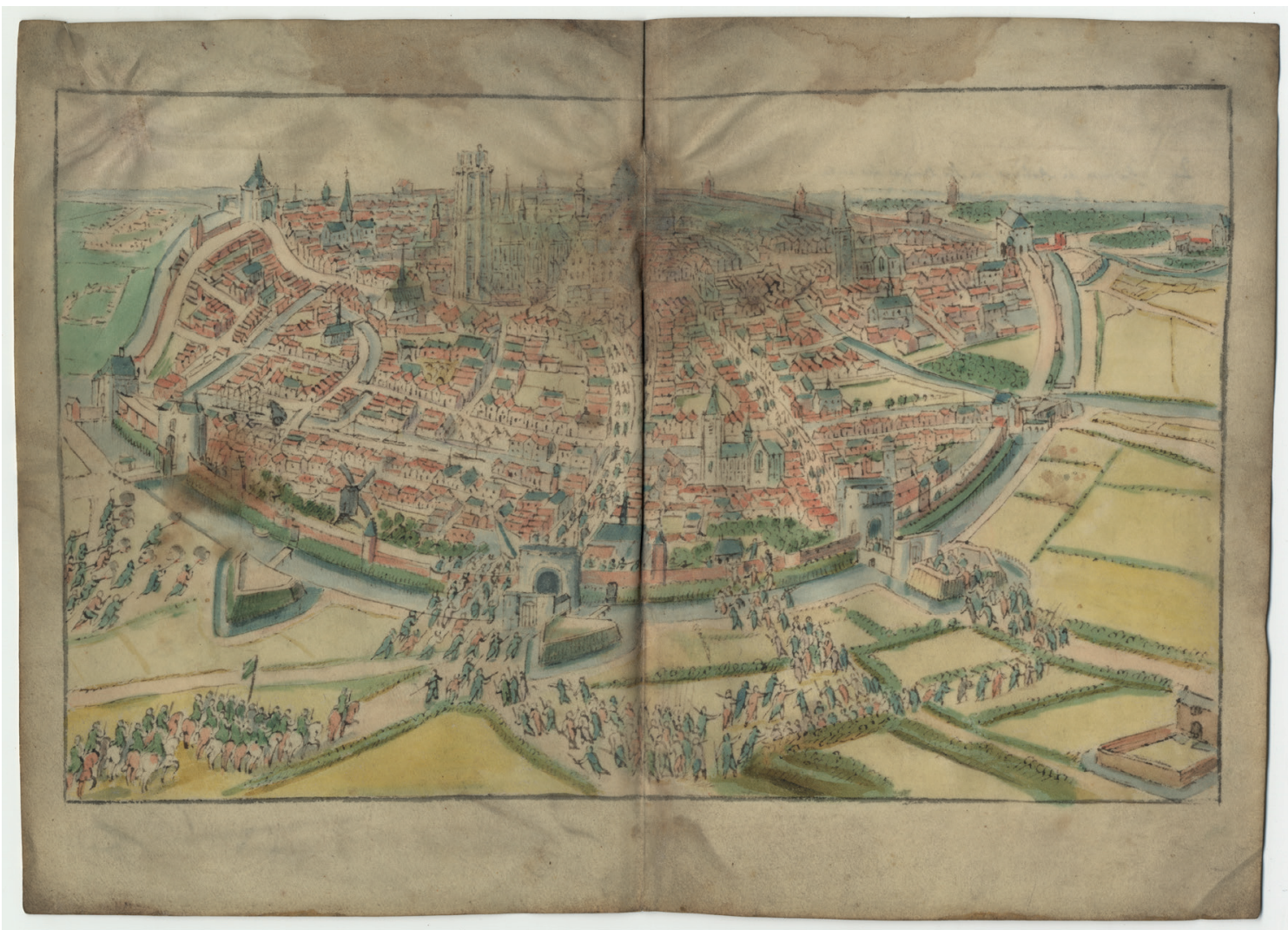

[Fig. 3] Anonymous artist, [Surprise de Malines par les troupes des états, le 9 avril 1580], Royal Library of Belgium, II 1388, fols 1v-2r]

One of the main reasons why this cityscape presents an 'emptier' impression than that depicting the Spanish Fury, is the fact that the outskirts of the city are shown as less densely built than before. This, in fact, concurs with historical reality. As mentioned before, a moderately antiroyalist city magistrate had decided to demolish and burn down all buildings outside the city walls in 1578 , so as to prevent them from being used by the enemy to fortify any position. This, then, is the main reason for the rather greenish countryside surrounding the city. Conveniently, the space vacated by the demolished buildings was gradually used to build modern fortifications, some of which must have been completed by 1580 , even if it is clear that the entire defensive fortification programme was never fully realised. ${ }^{38}$ The cityscape quite rightly shows some of the triangular sconces that were the modest beginnings of modern fortification around the city of Mechelen.

Het calvinistisch bewind, 352. Another similar banner is said to have been wielded by a Dionijs vanden Tempel (ms. 15.662, fol. 3r) He was under the command of (and possibly related to?) Olivier van den Tympel, who as governor of rebellious Brussels was one of the main instigators of the taking of Mechelen for the rebels in 1580, see Marnef, Het calvinistisch bewind, 143-144.

(38) Installé, 'Eigentijdse (tot 1800) oude gedrukte plattegronden', 36-37. 
Both the detail of the banner and the way in which the outskirts of the city have been depicted confirm that we are dealing with an image of the English Fury, even if no contemporary title or chronogram explicitly states this, as in the case of the cityscape showing the Spanish Fury. The latter was far livelier, with an explicit portrayal of the duke of Alva, many more soldiers and parts of the city in flames. One could conclude that the maker of these cityscapes was rather more outraged by the sack of 1572 than he was by that of 1580, and therefore decided to present the English Fury in a less explicit manner. But without knowing anything more about the production context of these images, we cannot be sure about any such interpretation.

\section{VUE VOL D'OISEAU DE LA VILLE DE MALINES, VERS 1580}

Parchment, approximately $330 \mathrm{~mm}$ by $240 \mathrm{~mm}$, folded in the middle but now kept unfolded. Interestingly, and in contrast to the two previous cityscapes, this one has two needle holes with rust stains that seem to indicate that the sheet of parchment was pinned to something. A romantic might see it livening up an early seventeenth-century drawing room wall. The front side $(1 \mathrm{v}-2 \mathrm{r})$ shows a pen and watercolour rendering $(315 \times 200 \mathrm{~mm})$ of the city of Mechelen seen from the far north side. In terms of perspective, this cityscape is far closer to a 'map' than the previous two, even if the projection is still made from a diagonal perspective. Like the two others, this depiction is surrounded by an ink frame. In the upper left corner margin ( $1 \mathrm{v})$, a contemporary hand has noted down a list of the city gates. Because of the differences to the previously described cityscapes, I cannot be sure that this one too was made by the same artist. The back side $(2 \mathrm{v}-1 \mathrm{r})$ is blank, but shows traces of an erased ownership mark that may be dated to the seventeenth or eighteenth centuries, as well as the ownership marks of the Royal Library and the French title, probably given upon acquisition in the late nineteenth century.

The cityscape definitely stands out from the two depicting subsequent sacks of Mechelen in 1572 and in 1580. In fact, no specific event is going on: we are looking simply at a rendering of the city of Mechelen from a bird's-eye view in its state before 1578. So much becomes evident from the presence of many buildings outside the city walls (including the great beguinage for example, which is in the foreground). Most of these were demolished in 1578 , so if the drawing was not made before 1578 , or based on an example dating back to this time, it certainly was the artist's deliberate intention to show the city in its virgin state, that is to say, before the devastating changes it underwent in the 1570 s and 1580 s. There is no great attention to detail, but with the use of no more than four main colours (green, red, yellow and blue), the result is convincing enough. As is customary in these cases, the important religious buildings stand out in the overall image. What is peculiar is that one building in the background has also received more considerable attention than others, a fortification in the outside borough of Nekkerspoel, traces of which remain to this day. ${ }^{39}$

(39) Agentschap Onroerend Erfgoed (Vlaams Gewest): Kasteeldomein De Borght (ID 1470, Nekkerspoel, Mechelen). https://id.erfgoed.net/erfgoedobjecten/1470 (consulted 29 June 2017). 


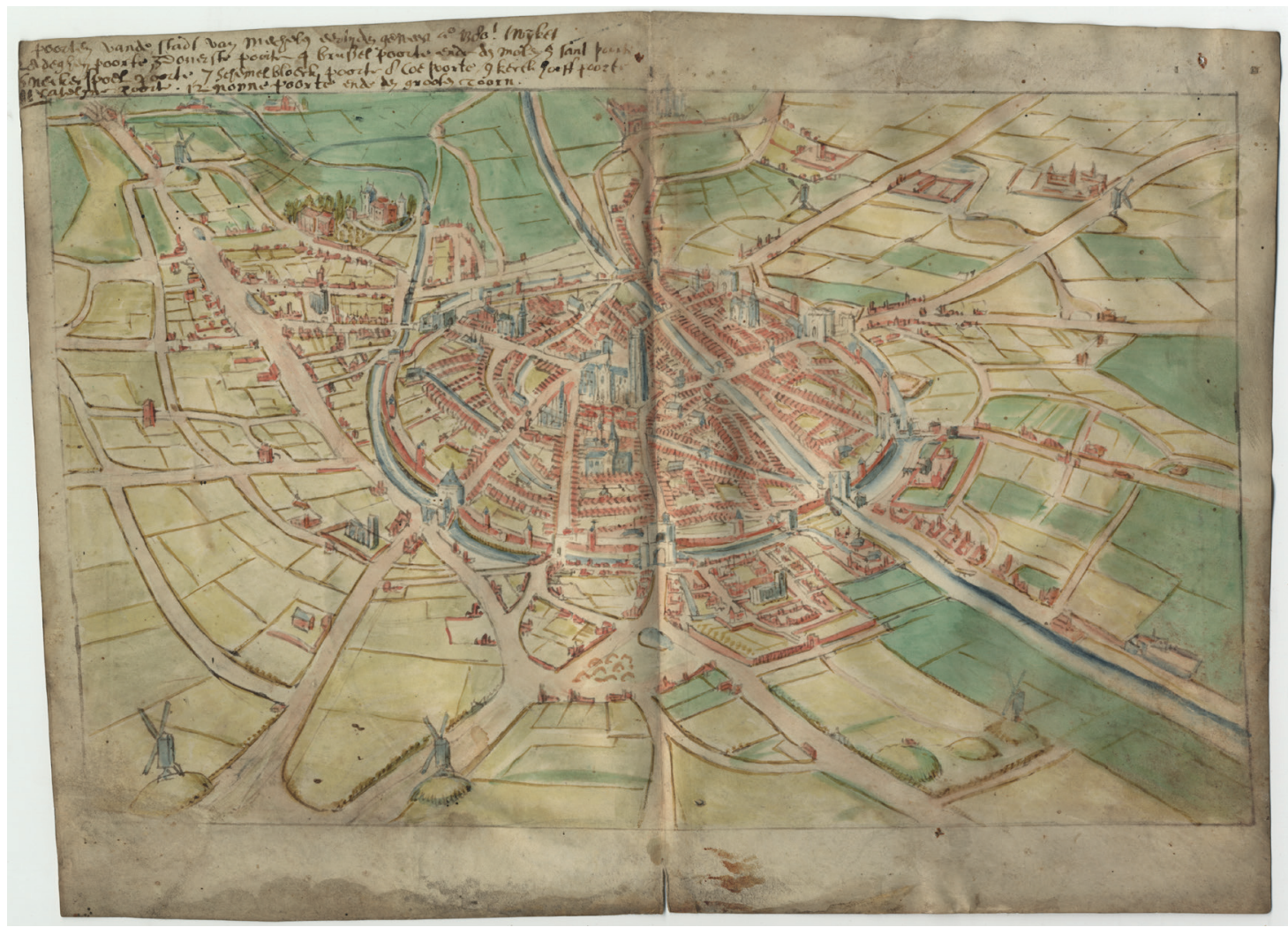

[Fig. 4] Anonymous artist, [Vue vol d'oiseau de la ville de Malines, vers 1580], Royal Library of Belgium, II 1388, fols 1v-2r]

The note in the upper left margin of the cityscape sums up the gates of Mechelen, starting with the 'Winketpoort' in the right hand side of the foreground, where the river Dyle leaves the city and then working counterclockwise around the image:

poorten vande stadt van mechelen eertyden geueest [?] anno 1380! Wijket

2 Adeghem poorte, 3 Douerste poorte, 4 Brußelpoorte ende den molen 5 sant poorte

6 Neckerspoel poorte 7 Schemelbloeckpoorte 8 Coepoorte, 9 Kerckhoeffpoorte [10?]

11 Catelynepoorte . 12 Nonnepoorte ende den grooten toorn

Part of the reason for the artist/author to explicitly make note of these gates may lie in the fact that they were rapidly losing their importance in the context of modern warfare. When in 1578, it was decided to demolish most of the outskirts of the city, the gates as well were partly demolished, or at least reduced in height. With the increasing power of artillery, high gates were of no particular use and would even present more danger to the besieged than to the attackers. ${ }^{40}$

(40) Kocken, 'De stadsomwallingen en -poorten', 193. Compare in general terms P. Martens, Militaire architectuur en vestingoorlog in de Nederlanden tijdens het regentschap van Maria van Hongarije (1531-1555): de ontwikkeling van de gebastioneerde vestingbouw. (Leuven: unpublished doctoral dissertation, 2009). 
In its simplicity and its modest use of colours, this rendering of the city of Mechelen resembles the map made around 1560 by Jacob van Deventer, but the projection is entirely different. Van Deventer drew a real 'map' with a vertical projection, whereas this image still shows Mechelen from a diagonal bird's eye view. Also, the north-south orientation of Van Deventer's map, so common to the modern eye, is not present in the cityscape, which overlooks the city from the northwest side, placing the horizon in the southeast.

\section{THE CITYSCAPES IN THE CONTEXT OF CONTEMPORARY DEPICTIONS OF THE CITY OF MECHELEN}

One wonders where artists working in the early decades of the seventeenth century got the inspiration for the three cityscapes described here. While the chronograms, which can be found in several contemporary sources, provide some idea on the circulation of this material, there is no parallel in the historical engravings for the iconography of the cityscapes themselves. Both the series of engravings by Hogenberg in Aitsinger's history, and the series in Baudartius' chronicle do deal with the sacks of Mechelen in 1572 and 1580, but show scenes of robbery and cruelty inside the city rather than a rendering of the entirety of Mechelen. In this respect, the cityscapes in the Royal Library rather resemble depictions from other sources, such as Lodovico Guicciardini's description of the Low Countries, or an engraving by Frans Hogenberg - again Hogenberg - used in several city atlases printed in the 1570 s and 1580s in Cologne. ${ }^{41}$ But if we confront these maps to the cityscapes discussed here, the projection does not match. As far as I have been able to ascertain, there is no contemporary printed source that could have been the basis for the parchment depictions in terms of iconography and cartographic projection.

The basic idea, however, to combine a rendering of a city with events occurred during the Rebellion, was not uncommon at the end of the sixteenth century and the beginning of the seventeenth. I have referred to Baudartius and Aitsinger, but there are examples of this type of 'iconographic memory' in other media as well. Close to Mechelen, there is the iconographical tradition around the military events in Lier in 1595, when the city was surprised in the early morning of 14 October by Estates troops, but reconquered for the Crown the same day by militia and garrison troops from Antwerp and Mechelen. ${ }^{42}$ To celebrate this

(41) The well-known series made by G. Braun \& F. Hogenberg (Civitates orbis terrarum) contains two renderings of the city of Mechelen. One shows the skyline of the city, in a horizontal projection from the point of view of a traveller arriving at the gates, another is more like a map, and could have been based on a map of the city made by Jan van Hanswijck in the 1570s. See Installé, 'Eigentijdse (tot 1800) oude gedrukte plattegronden', 30-31. The projection in Guicciardini, Beschryvinghe van alle de Neder-Landen anderssins ghenoemt Neder-Duytslandt, door M. Lowijs Guicciardijn... Amsterdam: Willem Jansz, 1612 [Facsimile edition, Amsterdam: Facsimile Uitgaven Nederland, 1968], [130-131] is similar enough to concur Installé's assumption that it could have been based on Hogenberg.

(42) An outdated account, but a pleasant read is G.J. Avontroodt, De furie of Lier, op den 14den October 1595 door den vyand verrast en door de burgers van Antwerpen en Mechelen hernomen. (Lier: Van In, 1840). 


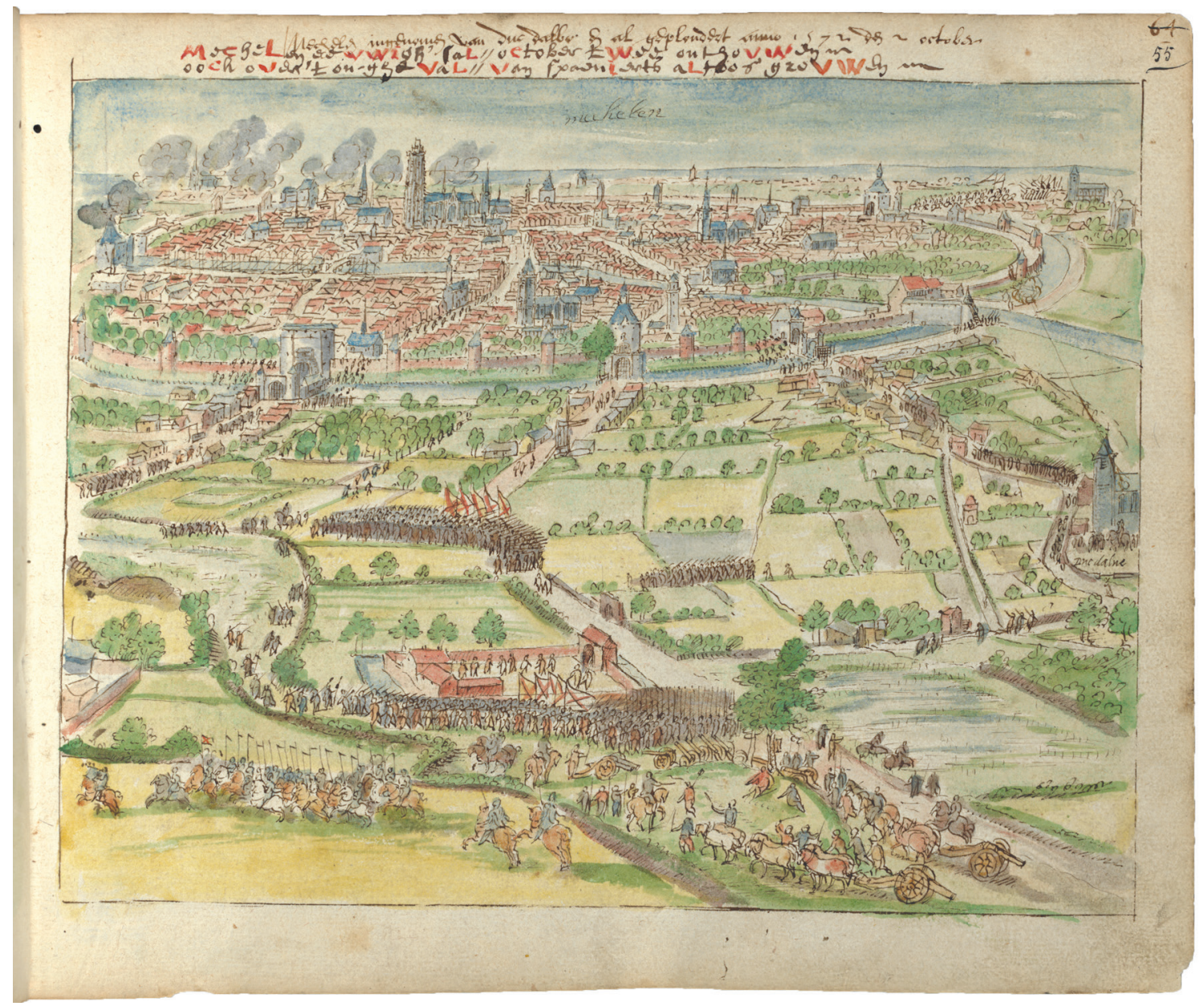

[Fig. 5] Anonymous artist, Mechelen ingenomen van duc dalbe ende al geplondert anno 1572 den 2 october, Royal Library of Belgium, Ms. 22.089, fol. 55r.]

event, the city of Mechelen commissioned a monumental painting depicting the events of the day with a group portrait of the main shooting guild members in the foreground. ${ }^{43}$ This iconographical programme was copied in Lier itself, albeit leaving out the Mechelen militia for evident reasons. ${ }^{44}$ The projection of both however, with a horizontal foreground and a rather more diagonal projection of the city in which the events took place, reminds of the two Fury cityscapes discussed here.

Aside from paintings, there are also examples in manuscript form that may serve as a comparison. The manuscript by the Mechelen rhetorician Willem de Gortter, which has been mentioned before, contains a cityscape of Mechelen spanning two full pages. This

(43) See Caers, 'In fide constans?', 242-243.

(44) L. Coenen, 'Lier en lyriana in de verzameling oude schilderijen van het stedelijk museum Wuyts-Van Campen en Baron Caroly,' Post factum: jaarboek voor geschiedenis en volkskunde 3 (2011), 53-93. 


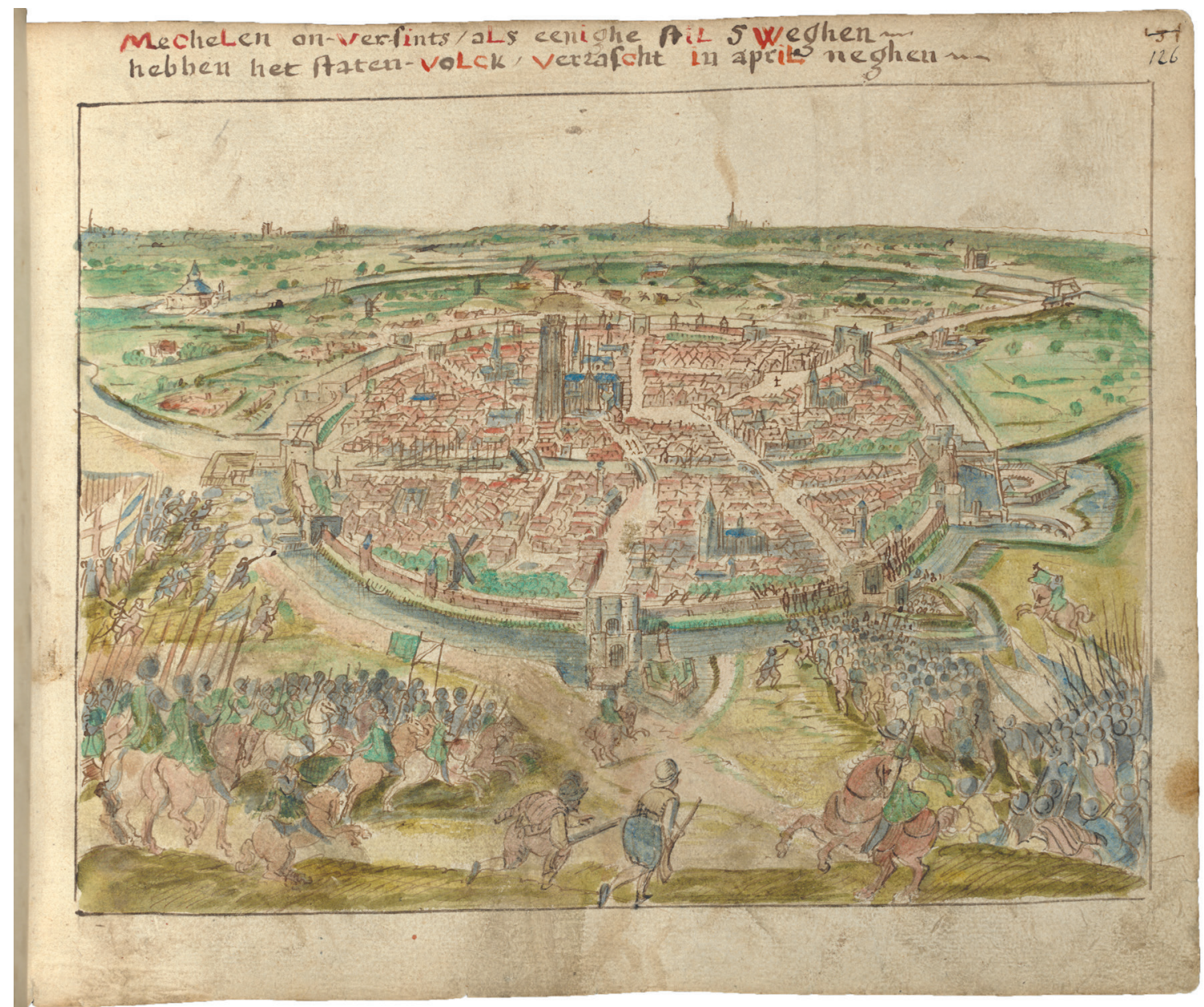

[Fig. 6] Anonymous artist, [English Fury in Mechelen, 1580], Royal Library of Belgium, Ms. 22.089, fol. 126r]

however, has clearly been based on the 'skyline' image in Braun \& Hogenberg's Civitates orbis terrarium in that it shows Mechelen from the perspective of an arriving traveller. ${ }^{45} \mathrm{An}$ other interesting parallel is a rather bulky paper manuscript that is also in the Royal Library, under reference number 22.089. It contains over a hundred drawings of scenes and battles of the Rebellion, mostly executed in ink and watercolour, although not all of them have been coloured. The renderings of the Spanish (1572) and English (1580) furies in Mechelen are indeed very similar to the cityscapes discussed here, even if they show Mechelen from a viewpoint farther away from the city, including more of the surrounding countryside in the image. ${ }^{46}$

(45) Brussels, Royal Library, ms. 15.662, fols 29v-30r.

(46) Brussels, Royal Library, ms. 22.089, [p. 55] and [p. 126]. 
The depiction of the soldiers and the way they enter the city is very similar. Even the detail of the desperate canon shot at the church of Muizen is included. A notable difference is that in both images, there is much more military activity, with numerous soldiers and officers on horseback, both inside and outside the city, many identifiable by their banners. How exactly both manuscripts (and their artists or reception contexts) are related - one could think of a common source - would require a more thorough investigation of manuscript 22.089 than is possible within the scope of this article. My impression, however, is that many of the renderings in this bulky album are heavily indebted to contemporary iconography in print, such as the engravings Hogenberg made for Aitsinger's chronicle. For the discussion here, it is therefore interesting to note that apparently contemporaries copied engravings in manuscript form, or collected iconographical renderings of stages of the Rebellion.

The collection of three parchment sheets dealing with subsequent stages of the unrest in Mechelen, then, may well have been a conscious collection by someone interested in the history of the city in this period. Because the ownership marks and any other references to contemporary owners have been erased or are lacking, it is unfortunately impossible to draw any closer to the context in which these renderings were made or initially received. I believe however, that added to what we already know about contemporary cartography, chorography and historiography in Mechelen in this period, it might be possible to connect them to contemporary sources in other types of media and genres. It is interesting to note that Jacob van Deventer spent a great part of his life in Mechelen, as did Frans Hogenberg. At the same time, it has been shown that the contexts of cartography and historiography in Mechelen overlapped to a great extent. ${ }^{47}$ Add to this the keen interest in the history of the city around 1600 and the will to glorify its past through various media, and we may indeed come closer to drawing a more vivid background to the cityscapes in the Royal Library.

(47) Caers, Vertekend verleden, 81-101. 
